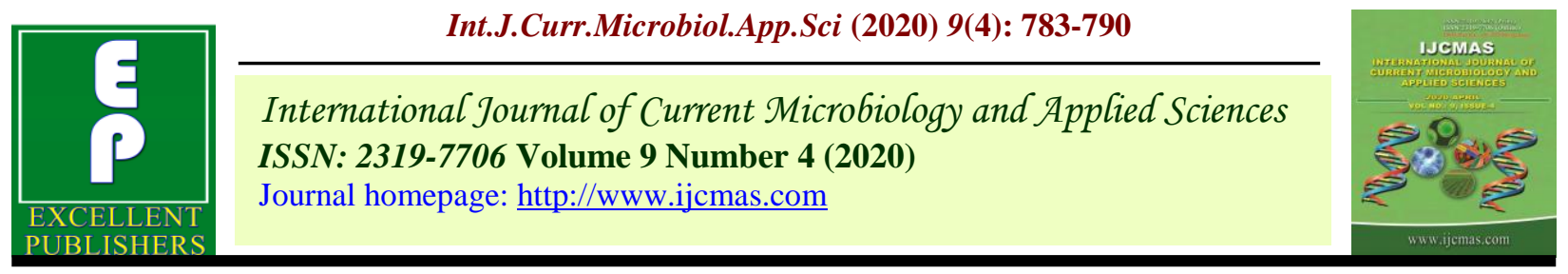

Original Research Article

https://doi.org/10.20546/ijcmas.2020.904.093

\title{
Knowledge Retaining Abilities of Dairy Farmers: Post-Training Analysis
}

\author{
Rakesh Roy $^{1 *}$, B. D. Kharga ${ }^{2}$ Bankim Chandra Rudra ${ }^{1}$, Adwaita Mondal ${ }^{1}$, Paramita \\ Bhowmik $^{1}$ and Debjyoti Majumder ${ }^{1}$
}

\author{
${ }^{1}$ Malda Krishi Vigyan Kendra, UBKV, Ratua, Malda-732205, WB, India \\ ${ }^{2}$ Darjeeling Krishi Vigyan Kendra, UBKV, Kalimpong-734301, WB, India \\ *Corresnondino author
}

\section{A B S T R A C T}

\section{Keywords}

Scientific dairy farming, Darjeeling, Knowledge retaining ability, Training

Article Info

Accepted:

07 March 2020

Available Online:

10 April 2020
The study was conducted to assess knowledge retaining ability of dairy farmers in Darjeeling district who had received on campus training from Darjeeling Krishi Vigyan Kendra on scientific dairy farming practices. The study was conducted on among 100 dairy farmers who had received on campus training during 2015-16 and 2016-17. For assessment of knowledge retaining abilities, personal interview with structure schedule was conducted in five phages (i.e., pre-training, posttraining, 3 months post-training, 6 months post-training and 12 months posttraining). The study shows that the respondents had significant increase in mean knowledge level in healthcare followed by breeding, feeding and management during post-training. Mean knowledge level of the dairy farmers at 3 months, 6 months and 12 months post-training was found highest in breeding practices followed by healthcare. The study also shows the dairy farmers had significant knowledge gain during post-training but there had been significantly losses in knowledge level at different time intervals to post-training.

\section{Introduction}

Domestic milk production in India has increased from 155.5 MMT in 2015-16 to 163.7 MMT in 2016-17, registering a gain of 5.3 per cent against the backdrop of two consecutive drought years during 2014-15 and 2015-16. Per capita availability of milk has been raised up to $337 \mathrm{gm}$ in 2015-16 which is more than the world average (NDDB, 2017). Though India is leading in production and consumption, still it is far behind in term of productivity. One of the major reasons of low productivity could be due to traditional dairy farming practices by the farmers. Numbers of improved technologies have been developed in the previous years in the field of dairying sector; however, these technologies have not been successfully transferred from the scientific institution to the grass root at the desired level.

This may be due to lack of coordinated efforts been taken from different institutes. Production and productivity are one of the most important considerations to determine 
the profitability of dairy animals which depends on four dimensions viz. breeding, feeding, health care and management practices (Manjusha et al., 2016). Knowledge about modern dairy farming practices is prerequisite for adoption of it which ultimately improves the dairy production and productivity. Darjeeling Krishi Vigyan Kendra had taken up various programs to enhance the knowledge level of dairy farmers in the district but it has been noticed sometimes that the same farmers attend these kinds of programmes and behave to be unfamiliar to these technologies. Therefore, it has been felt to study the knowledge retaining ability of the dairy farmers in the study area so that trainings and demonstration programmes can be planned for the farmers at different time intervals.

\section{Materials and Methods}

\section{Study area}

This study was conducted in Sub-Himalayan region of West Bengal during April 2015 to May 2018.

\section{Sampling method}

The study was conducted among the dairy farmers in Darjeeling district who have received on campus training from Darjeeling Krishi Vigyan Kendra on scientific dairy farming practices during 2015-16 and 201617. Assessment of knowledge retaining ability was conducted in five phages (i.e., pretraining, post-training, 3 months post-training, 6 months post-training and 12 months posttraining) among 100 randomly selected respondents who had received training in scientific dairy farming practices during these two years from Darjeeling Krishi Vigyan Kendra. It was taken care that the same respondents were interviewed at different time intervals to the post training.

\section{Data collection and analysis}

Data was collected from different aspect of scientific dairy farming practices like scientific breeding, feeding, management and healthcare practices. A score of 1 was given for each correct answer and 0 for wrong answer to assess change in knowledge level. The data was coded and entered into excel spreadsheets. Simple statistical analysis such as frequency, percentage, mean, standard deviation and pair t-test were used using SPSS 20 for interpretation of the data.

\section{Results and Discussion}

\section{Knowledge about breeding practices at different time interval}

Table 1 shows that 97 percent of the respondents were having knowledge about the timing of artificial insemination during posttraining while only 52 percent were having knowledge during pre-training. Knowledge retaining ability of the respondents regarding timing of artificial insemination to dairy animals at 3-12 months of post-training was between 92-81percent. Knowledge about gestation period of cow during post-training found among 94 percent of the respondents while 56 percent during pre-training. Knowledge retaining ability of the respondents regarding the gestation period of cow at 3-12 months of post-training was between $85-78$ percent. Knowledge about the period of insemination after normal calving was found among 85 percent of the respondents during post-training while 77 percent during pre-training. Knowledge retaining ability of the respondents regarding the period of insemination after normal calving at 3-12 months of post-training was between 82-71 percent. Knowledge about the symptoms of animal in heat was found among 95 percent of the respondents during posttraining while 66 percent during pre-training. 
Knowledge retaining ability of the respondents regarding the symptoms of animal in heat at 3-12 months of post-training was between 87-69 percent. Knowledge about the sign and symptoms of parturition was found among 87 percent of the respondents during post-training while only 40 percent during pre-training. Knowledge retaining ability of the respondents regarding the sign and symptoms of parturition at 3-12 months of post-training was between 83-67 percent. Knowledge retaining abilities of the respondents for other breeding practices at 12 months of post-training was below 50 percent. Similar findings were reported by Sharma et al., (2014).

The study further shows mean knowledge score of the respondents about breeding practices during pre-training and post-training was 4.50 and 8.64 respectively out of 10 point score. The mean knowledge score of the respondents at 3 months, 6 months and 12 months of post-training were 7.59, 6.88 and 5.71 respectively in scientific breeding practices. This implied that knowledge gained by the respondents due to training programme and knowledge loss due to time factors with regard to scientific breeding practices was substantial which has also been supported by the significance of the t-value (Table 1).

\section{Knowledge about feeding practices at different time interval}

Table 2 depicts that 95 percent of the respondents were having knowledge about feeding of colostrum to newly born calf during post-training while 69 percent of the respondents during pre-training. Knowledge retaining ability of the respondents regarding feeding of colostrum to new born calf at 3-12 months of post-training was between 82-72 percent. Knowledge about feeding colostrum to newly born calves at least 3 days of its birth was found among 90 percent of the respondents during post-training while 69 percent during pre-training. Knowledge retaining ability of the respondents regarding feeding of colostrum to new born calves at least 3days of its birth at 3-12 months of posttraining was between 82-61 percent. Knowledge about feeding of mineral mixture was found among 87 percent of the respondents during post-training while only 4 percent during pre-training.

Knowledge retaining ability of the respondents regarding feeding of mineral mixture at 3-12 months of post-training was between 63-53 percent. Knowledge retaining abilities of the respondents about other feeding practices at 12 months of posttraining was below 50 percent. Similar findings were reported by Sharma et al., (2014); Kumar et al., (2013); Meena et al., (2009) and Sharma et al., (2007).

The study further shows that mean knowledge score of the respondents in scientific feeding practices during pre-training and post-training were 2.38 and 8.61 respectively out of 10 point score. The mean knowledge score of the respondents at 3 months, 6 months and 12 months of post-training were $6.83,5.97$ and 4.48 respectively. This implied that knowledge gained by the respondents due to training programme and knowledge loss due to time factors with regard to scientific feeding practices was substantial which has also been supported by the significance of the t-value (Table 2).

\section{Knowledge about management practices at different time interval}

Table 3 reveals that 95 percent of the respondents during post-training while 61 percent of the respondents during pre-training were having knowledge about maintaining cleanliness of cattle shed. Knowledge retaining ability of the respondents regarding 
maintaining cleanliness of cattle shed at 3-12 months of post-training was between 87-69 percent. Knowledge about dry period to be allowed for lactating pregnant animal was found among 90 percent of the respondents during post-training while 32 percent during pre-training. Knowledge retaining ability of the respondents regarding dry period to be allowed for lactating pregnant animal at 3-12 months of post-training was between 82-66 percent.

Knowledge about providing clean and fresh drinking water to animals was found among 77 percent of the respondents during posttraining while 55 percent during pre-training. Knowledge retaining ability of the respondents regarding providing clean and fresh drinking water to the animals at 3-12 months of post-training was between 72-63 percent. Knowledge about protection of animal during cold was found among 71 percent of the respondents during posttraining while 29 percent during pre-training.

Knowledge retaining ability of the respondents regarding protection of animal during cold at 3-12 months of post-training was between 67-56 percent. Knowledge about castration of male livestock was found among 81 percent of the respondents during posttraining while 23 percent during pre-training.

Knowledge retaining ability of the respondents about castration of male livestock at 3-12 months of post-training was between 75-50 percent. Knowledge retaining abilities of the respondents about other practices of management at 12 months of post-training was below 50 percent. Similar findings were reported by Manivannan et al., (2008).

The study further shows that the mean knowledge score of the respondents in scientific management practices during pretraining and post-training was 2.51 and 7.71 respectively out of 10 point score. The mean knowledge score of the respondents at 3 months, 6 months and 12 months of posttraining were $6.65,5.47$ and 4.59 respectively in scientific management practices.

This implied that knowledge gained by the respondents due to training programme and knowledge loss due to time factors with regard to scientific management practices was substantial which has also been supported by the significance of the $\mathrm{t}$-value (Table 3 ).

\section{Knowledge about animal healthcare practices at different time interval}

Table 4 shows that 97 percent of the respondents were having knowledge about symptoms of sick animals during posttraining while 51 percent during pre-training. Knowledge retaining ability of the respondents regarding symptoms of sick animals at 3-12 months of post-training was between 84-72 percent.

Knowledge about symptoms of foot and mouth disease was found among 89 percent of the respondents during post-training while 51 percent during pre-training. Knowledge retaining ability of the respondents regarding symptoms of foot and mouth disease at 3-12 months of post-training was between 78-67 percent. Knowledge about symptoms of healthy animals was found among 92 percent of the respondents during post-training while 32 percent during pre-training.

Knowledge retaining ability of the respondents regarding symptoms of healthy animals at 3-12 months of post-training was between 79-65 percent. Knowledge about timely vaccination against infectious diseases was found among 91 percent of the respondents during post-training while 23 percent during pre-training. Knowledge retaining ability of the respondents regarding 
timely vaccination against infectious diseases at 3-12 months of post-training was between 87-63 percent. Knowledge about timely deworming was found among 84 percent of the respondents during post-training while 27 percent during pre-training.

Knowledge retaining ability of the respondents regarding timely deworming at 312 months of post-training was between 6659 percent. Knowledge retaining abilities of the respondents about other animal healthcare practices at 12 months of post-training was below 50 percent. Similar findings were reported by Aulakh et al., (2011).

The study further shows that the mean knowledge score of the respondents in scientific animal healthcare practices during pre-training and post-training was 2.71 and 8.80 respectively out of 10 point score. The mean knowledge score of the respondents at 3 months, 6 months and 12 months of posttraining were $7.03,6.00$ and 5.41 respectively in scientific animal healthcare practices. This implied that knowledge gained by the respondents due to training programme and knowledge loss due to time factors with regard to scientific healthcare practices was substantial which has also been supported by the significance of the t-value (Table 4).

\section{Overall difference of knowledge level at different time interval}

Table 5 shows that the overall mean knowledge score of the respondents in scientific dairy farming practices during pretraining and post-training was 12.10 and 33.76 respectively out of 40 point score. The overall mean knowledge score of the respondents at 3 months, 6 months and 12 months of post-training were $28.10,34.32$ and 20.19 respectively in scientific dairy farming practices. This implied that knowledge gained by the respondents due to training programme and knowledge loss due to time factors with regard to scientific dairy farming practices was substantial which has also been supported by the significance of the $t$-value.

Table.1 Shows knowledge on breeding practices at different time interval

\begin{tabular}{|c|c|c|c|c|c|c|}
\hline Sl. no. & Particulars & $\begin{array}{c}\text { Pre } \\
\text { Training }\end{array}$ & $\begin{array}{c}\text { Post } \\
\text { Training }\end{array}$ & $\begin{array}{l}\text { Post training } \\
\text { (3months) }\end{array}$ & $\begin{array}{c}\text { Post training } \\
\text { (6months) }\end{array}$ & $\begin{array}{r}\text { Post training } \\
\text { (12months) }\end{array}$ \\
\hline 1. & Breeds of cow & 32 & 71 & 60 & 55 & 41 \\
\hline 2. & Symptoms of animal in heat & 66 & 95 & 87 & 79 & 69 \\
\hline 3. & $\begin{array}{l}\text { Right time of Artificial } \\
\text { Insemination }\end{array}$ & 52 & 97 & 92 & 90 & 81 \\
\hline 4. & Pregnancy diagnosis & 33 & 72 & 59 & 55 & 40 \\
\hline 5. & $\begin{array}{l}\text { Period of insemination after normal } \\
\text { calving }\end{array}$ & 77 & 85 & 82 & 71 & 73 \\
\hline 6. & Selective breeding & 35 & 89 & 78 & 71 & 45 \\
\hline 7. & Gestation period of cow & 56 & 94 & 85 & 81 & 78 \\
\hline 8. & Sign and symptoms of parturition & 40 & 87 & 83 & 72 & 67 \\
\hline 9. & Dystocia & 37 & 88 & 67 & 63 & 44 \\
\hline 10. & Removal of placenta & 22 & 86 & 69 & 51 & 33 \\
\hline & Mean \pm SD & $4.50 \pm 3.53$ & $8.64 \pm 2.18$ & $7.59 \pm 2.62$ & $6.88 \pm 3.06$ & $5.71 \pm 3.26$ \\
\hline \multirow{4}{*}{\multicolumn{2}{|c|}{ t-value }} & $13.013 * *$ & & & & \\
\hline & & & \multicolumn{2}{|l|}{$6.598^{* *}$} & & \\
\hline & & & \multicolumn{3}{|c|}{$8.128 * *$} & \\
\hline & & & \multicolumn{4}{|c|}{$11.501 * *$} \\
\hline
\end{tabular}


Table.2 Shows knowledge about feeding practices at different time interval

\begin{tabular}{|c|c|c|c|c|c|c|}
\hline Sl. no. & Particulars & $\begin{array}{l}\text { Pre } \\
\text { Training }\end{array}$ & $\begin{array}{c}\text { Post } \\
\text { Training }\end{array}$ & $\begin{array}{l}\text { Post training } \\
\text { (3months) }\end{array}$ & $\begin{array}{c}\text { Post training } \\
\text { (6months) }\end{array}$ & $\begin{array}{r}\text { Post training } \\
\text { (12months) }\end{array}$ \\
\hline 1. & $\begin{array}{l}\text { Additional conc. feed to pregnant } \\
\text { cow in the advanced stage of } \\
\text { pregnancy }\end{array}$ & 25 & 87 & 75 & 55 & 41 \\
\hline 2. & $\begin{array}{l}\text { Feeding of colostrum to newly born } \\
\text { calf }\end{array}$ & 69 & 95 & 82 & 75 & 72 \\
\hline 3. & $\begin{array}{l}\text { Feeding colostrum to newly born } \\
\text { calves at least } 3 \text { days of its birth }\end{array}$ & 42 & 90 & 82 & 73 & 61 \\
\hline 4. & Practice to feed the newly born calf & 33 & 87 & 70 & 61 & 40 \\
\hline 5. & $\begin{array}{l}\text { Practice of feeding fodder and } \\
\text { concentrates }\end{array}$ & 37 & 79 & 62 & 56 & 43 \\
\hline 6. & $\begin{array}{l}\text { Feeding conc. mixture on the basis } \\
\text { of milk production }\end{array}$ & 0 & 89 & 67 & 57 & 31 \\
\hline 7. & Growing green fodder & 16 & 94 & 75 & 61 & 47 \\
\hline 8. & Feeding of mineral mixture & 4 & 87 & 63 & 62 & 53 \\
\hline 9. & Silage preparation & 0 & 69 & 46 & 40 & 24 \\
\hline 10. & $\begin{array}{l}\text { Feeding of right amount of milk to } \\
\text { calf }\end{array}$ & 12 & 74 & 61 & 57 & 36 \\
\hline \multirow{5}{*}{\multicolumn{2}{|c|}{$\begin{array}{c}\text { Mean } \pm \text { SD } \\
\text { t-value }\end{array}$}} & $2.38 \pm 1.04$ & $8.61 \pm 2.17$ & $6.83 \pm 2.13$ & $5.97 \pm 2.38$ & $4.48 \pm 2.31$ \\
\hline & & \multicolumn{2}{|c|}{$30.928^{* *}$} & & & \\
\hline & & & \multicolumn{2}{|c|}{$12.131 * *$} & & \\
\hline & & & \multicolumn{3}{|c|}{$14.752 * *$} & \\
\hline & & & \multicolumn{4}{|c|}{$19.973 * *$} \\
\hline
\end{tabular}

$* * \mathrm{p}<0.01$

Table.3 Shows knowledge about management practices at different time interval

\begin{tabular}{|c|c|c|c|c|c|c|}
\hline Sl. no. & Particulars & $\begin{array}{c}\text { Pre } \\
\text { Training }\end{array}$ & $\begin{array}{l}\text { Post } \\
\text { Training }\end{array}$ & $\begin{array}{c}\text { Post training } \\
\text { (3months) }\end{array}$ & $\begin{array}{l}\text { Post training } \\
\text { (6months) }\end{array}$ & $\begin{array}{r}\text { Post training } \\
\text { (12months) }\end{array}$ \\
\hline 1. & Clean milk production & 12 & 71 & 62 & 54 & 42 \\
\hline 2. & Maintaining cleanliness of cattle shed & 61 & 95 & 87 & 79 & 69 \\
\hline 3. & $\begin{array}{l}\text { Dry period to be allowed for lactating } \\
\text { pregnant animal }\end{array}$ & 32 & 90 & 82 & 64 & 66 \\
\hline 4. & $\begin{array}{l}\text { Caring of animal of different age } \\
\text { group }\end{array}$ & 17 & 72 & 67 & 62 & 41 \\
\hline 5. & Protection of animal during cold & 29 & 71 & 67 & 61 & 56 \\
\hline 6. & $\begin{array}{l}\text { Providing clean and fresh drinking } \\
\text { water to the animals }\end{array}$ & 55 & 77 & 69 & 72 & 63 \\
\hline 7. & Dehorning of newly born calf & 00 & 52 & 20 & 13 & 8 \\
\hline 8. & Castration & 23 & 81 & 75 & 56 & 50 \\
\hline 9. & Practice of full hand way of milking & 15 & 89 & 76 & 62 & 47 \\
\hline 10. & Maintaining records & 7 & 73 & 60 & 24 & 17 \\
\hline \multirow{5}{*}{\multicolumn{2}{|c|}{$\begin{array}{c}\text { Mean } \pm \text { SD } \\
\text { t-value }\end{array}$}} & $2.51 \pm 1.14$ & $7.71 \pm 2.02$ & $6.65 \pm 2.07$ & $5.47 \pm 2.12$ & $4.59 \pm 2.02$ \\
\hline & & \multicolumn{2}{|c|}{$27.896 * *$} & & & \\
\hline & & & \multicolumn{2}{|c|}{$8.347 * *$} & & \\
\hline & & & \multicolumn{3}{|c|}{$14.440 * *$} & \\
\hline & & & \multicolumn{4}{|c|}{$16.533 * *$} \\
\hline
\end{tabular}

$* * \mathrm{p}<0.01$ 
Table.4 Shows knowledge about animal healthcare practices at different time interval

\begin{tabular}{|c|c|c|c|c|c|c|}
\hline SI. no. & Particulars & $\begin{array}{c}\text { Pre } \\
\text { Training }\end{array}$ & $\begin{array}{c}\text { Post } \\
\text { Training }\end{array}$ & $\begin{array}{c}\text { Post training } \\
\text { (3months) }\end{array}$ & $\begin{array}{c}\text { Post training } \\
\text { (6months) }\end{array}$ & $\begin{array}{r}\text { Post training } \\
\text { (12months) }\end{array}$ \\
\hline 1. & Important diseases of dairy animal & 16 & 78 & 63 & 54 & 48 \\
\hline 2. & Symptoms of sick animals & 51 & 97 & 84 & 77 & 72 \\
\hline 3. & Symptoms of healthy animals & 32 & 92 & 79 & 71 & 65 \\
\hline 4. & $\begin{array}{l}\text { Timely vaccination against infectious } \\
\text { diseases }\end{array}$ & 23 & 91 & 87 & 75 & 63 \\
\hline 5. & Timely deworming & 27 & 87 & 66 & 65 & 59 \\
\hline 6. & Symptoms of foot and mouth disease & 51 & 89 & 78 & 71 & 67 \\
\hline 7. & $\begin{array}{l}\text { Treatment of umbilical cord to new } \\
\text { born calf }\end{array}$ & 33 & 94 & 60 & 41 & 38 \\
\hline 8. & $\begin{array}{l}\text { Segregating the diseased animals } \\
\text { suffering from contagious diseases }\end{array}$ & 15 & 87 & 63 & 52 & 47 \\
\hline 9. & Proper disposal of carcass & 9 & 79 & 57 & 43 & 39 \\
\hline 10. & Proper disposal of waste & 14 & 86 & 66 & 51 & 43 \\
\hline \multirow{5}{*}{\multicolumn{2}{|c|}{ t-value }} & $2.71 \pm 1.11$ & $8.80 \pm 1.92$ & $7.03 \pm 2.08$ & $6.00 \pm 2.25$ & $5.41 \pm 2.27$ \\
\hline & & \multicolumn{2}{|c|}{$34.516^{* *}$} & & & \\
\hline & & & \multicolumn{2}{|c|}{$12.590 * *$} & & \\
\hline & & & \multicolumn{3}{|c|}{$16.532 * *$} & \\
\hline & & & \multicolumn{3}{|c|}{$18.832 * *$} & \\
\hline
\end{tabular}

$* * \mathrm{p}<0.01$

Table.5 Shows overall difference of knowledge level of dairy farmers at different time interval

\begin{tabular}{|c|c|c|c|c|c|c|}
\hline \multicolumn{2}{|c|}{ Particulars } & \multirow{2}{*}{$\begin{array}{c}\begin{array}{c}\text { Pre } \\
\text { Training }\end{array} \\
12.10 \pm 5.92\end{array}$} & \multirow{2}{*}{$\begin{array}{c}\text { Post } \\
\text { Training } \\
33.76 \pm 7.88\end{array}$} & \multirow{2}{*}{$\begin{array}{c}\text { Post training } \\
\text { (3months) } \\
28.10 \pm 8.53\end{array}$} & \multirow{2}{*}{$\begin{array}{c}\text { Post training } \\
\text { (6months) }\end{array}$} & \multirow{2}{*}{$\begin{array}{c}\text { Post training } \\
\text { (12months) } \\
20.19 \pm 8.81\end{array}$} \\
\hline \multirow{5}{*}{$\begin{array}{c}\text { Scientific } \\
\text { dairy } \\
\text { farming } \\
\text { practices }\end{array}$} & Mean \pm SD & & & & & \\
\hline & \multirow[t]{4}{*}{ t-value } & \multicolumn{2}{|c|}{$34.508 * *$} & & & \\
\hline & & & \multicolumn{2}{|c|}{$11.641^{* *}$} & & \\
\hline & & & \multicolumn{3}{|c|}{$15.093 * *$} & \\
\hline & & & \multicolumn{4}{|c|}{$20.724 * *$} \\
\hline
\end{tabular}

$* * \mathrm{p}<0.01$

The study has shown that the training programs on scientific dairy farming practices have substantially increased the knowledge level of the dairy farmers but with passing time knowledge of the dairy farmers gradually decreases. For increasing and retaining of these scientific knowledge repeated stimulus need to be given to the farmers.

Repeated program with the same lot of farmers at different time intervals will help in retaining the scientific knowledges and thereby adoption of the scientific practices.
Line departments dealing with the farmers for transfer of technologies should take up integrated efforts so that the modern technologies are successfully transferred from the scientific institutions to the grass root level.

\section{References}

Aulakh, G.S., Yadav, J.S. and Singh R. (2011). Knowledge level of dairy farmers regarding recommended buffalo management practices. Journal of Dairying, Foods and Home Sci. 30(2):147-149. 
Kumar, B.R., Baskaran, D., Saraswathi, S. and Kumar, C.T.A. (2013). Impact of training program in adoption of cattlefeed computation by Farmer Interest Groups (FIGS) of Tamil Nadu. Tamil Nadu Journal of Veterinary and Animal Sciences 9(4):264-271.

Manivannan, A.N., Narmath and Uma, V. (2008). Knowledge level of dairy farmers on calf rearing practices. Journal of Extension Education 20(14):4131-4133.

Manjusha, J., Roy, R., Kumar, V. and Gupta, J. (2016). Productive and reproductive performance of dairy animals in Karnal district of Haryana. Indian Veterinary Journal 93(6):38-40.

Meena, B.S., Singh, A.K., Chauhan, J. and Sankhala, G. (2009). Farmers knowledge on feeding of dairy animals in Jhansi district. Indian Research Journal of
Extension Education 9(1):28-31.

NDDB. (2017) Annual Report 2016-17. https://www.nddb.coop/sites/default/file s/NDDB_AR_2016-17_Eng.pdf

Senthilkumar, K., Daisy, M., Kumaravel, V. and Mohan, B. (2014). Impact of KVK training on scientific method of goat rearing and feeding management of Azolla. International Journal of Science, Environment and Technology 3(6):2287-2292.

Sharma, M., Singh, G., and Keshava. (2014). Impact evaluation of training programmes on dairy farming in Punjab state. Indian Research Journal of Extension Education 14(1):105-108.

Sharma, P., Panda, S., Meena, B.S. and Singh, N.P. (2007). Knowledge and adoption of livestock feeding practices in Jhansi District of Bundelkhand. Indian Journal of Dairy Science 60(1):63-66.

\section{How to cite this article:}

Rakesh Roy, B. D. Kharga, Bankim Chandra Rudra, Adwaita Mondal, Paramita Bhowmik and Debjyoti Majumder. 2020. Knowledge Retaining Abilities of Dairy Farmers: Post-Training Analysis. Int.J.Curr.Microbiol.App.Sci. 9(04): 783-790.

doi: https://doi.org/10.20546/ijcmas.2020.904.093 